\title{
Avijit (Tultul) Lahiri (1948-2021): A friend, mentor and inspiration to all!
}

\author{
Jeffrey Leppo, $M D,{ }^{a}$ Prem Soman, $M D, P h D,{ }^{b}$ and Barry L. Zaret, $M^{c}$ \\ a University of Massachusetts School of Medicine, Worcester, MA \\ b University of Pittsburgh Medical Center, Pittsburgh, PA \\ c Robert W. Berliner Professor Emeritus of Medicine, Yale University School of Medicine, New \\ Haven, CT
}

Received Oct 1, 2021; accepted Oct 1, 2021

doi: $10.1007 / \mathrm{s} 12350-021-02828-y$

When Tultul floated by in a resort pool and mentioned that he really thought we could work together to make an international nuclear cardiology meeting, it seemed like an impossible dream. Within 3 years, we gathered almost 1,000 delegates for the first International Conference on Nuclear Cardiology (ICNC) meeting and had acquired enough organizational skills to incorporate ASNC as well. Dr. Lahiri's vision of a dedicated group of nuclear cardiologists leading an independent society to better patient care was a critical driving force to allow our field to stand on its own. Tultul found an event organizer in London, who ran the first ICNC meeting and then helped us to take it over as a partnership between ASNC, the European Association of Nuclear Medicine, and the European Society of Cardiology.

Tultul had an extensive medical knowledge and was an insightful and pioneering investigator who also trained and mentored us all for his entire professional career. His innumerable professional achievements include hundreds of peer review publications and invited lectureships as well as book chapters and seminal work with carvedilol and tetrofosmin. Dr. Lahiri was appropriately recognized as a member of the Royal College of Physicians, editorial boards, and leadership positions in numerous medical societies. He had a great ability to see how to combine all types of cardiac imaging to help direct better clinical care. He was also able to use his imaging skills to better evaluate new cardiac drugs as

Donations to the Avijit Lahiri Fellowship fund can be made at www.britishcardiacresearchtrust.org.

Reprint requests: Prem Soman, MD, PhD, University of Pittsburgh Medical Center, A-429 Scaife Hall, 200 Lothrop Street, Pittsburgh, PA 15213; somanp@upmc.edu

J Nucl Cardiol 2021;28:2503-5.

$1071-3581 / \$ 34.00$

Copyright (c) 2021 American Society of Nuclear Cardiology.

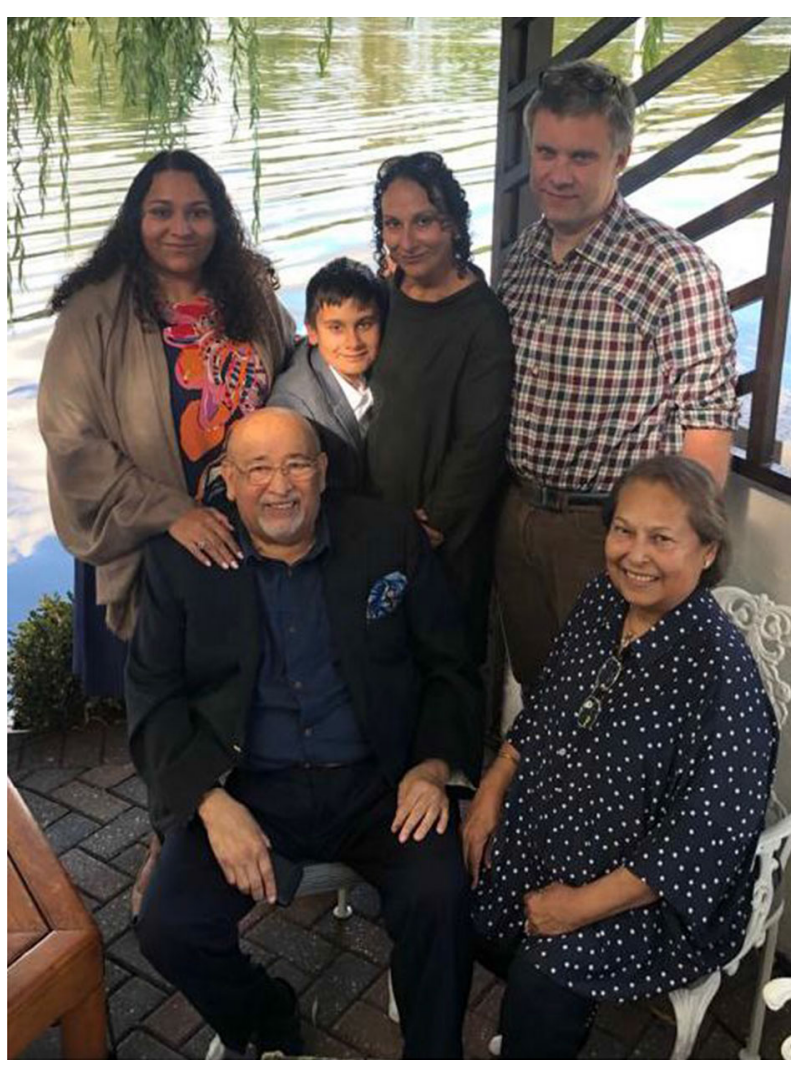

Photo: Avijit and Chobi Lahiri with Diya Lahiri, and Nayana, Arun, and James Swales in September 2020.

well as obtain prognostic information for high-risk patient groups.

Not only was he a superb clinician, skilled researcher, and investigator, but he was also a charming individual who had an inexhaustible love of life and zest for living that were positively contagious. It was always fun to work and especially play with Tultul. In addition to his immense medical and research skills, there was a 
devoted and loving family man. Of course, there was a close nuclear family but there was also a real sense that all his close friends, trainees, and staff were a very close part of his extended family. Abstract writing and practice presentations were frequently done in the Lahiri living room, fed from the Lahiri kitchen and often to the background of Indian classical music. There was always more than enough love, generosity, and hospitality to go around for everyone. What he taught his trainees went far beyond nuclear cardiology and included a love of art, music, and good wine.

Everyone who ever received an all-encompassing hug and kiss from Tultul would never doubt that they were truly loved as a member of the Lahiri clan. The membership was worldwide and continuously growing to include neighbors, artisans, patients, mentees, new friends, and friends of friends. There was always honest humility even though he was typically the smartest person in the room. If there was a hole in his repertoire, it might be cooking anything beyond fluffy eggs for breakfast. However, his culinary taste and oenophile knowledge made him a true gourmet.

It is not just his loving family that feels such a terrible loss. The extended family of friends and professional contacts is also experiencing a profound sense of bereavement as though a true family member has been lost. He was a founding father of Nuclear Cardiology and a superb human being. 


\section{LIGHT IN YOUR WINDOW \\ In memory of Avijit (Tultul) Lahiri \\ (1948-2021)}

We met in London, almost 40 years ago.

The light in your window shone brightly.

I moved closer,

attracted as moth to flame.

First, medicine, science.

Later art, poetry, philosophy,

the sitar, Tagore.

You introduced me to others

as your mentor.

More often,

you were the teacher.

Over the decades-

we traversed

Europe's cobble stone streets,

India's rural dirt paths,

convention halls, museums.

Your mind always awhirl-

enough energy

to power a city.

We pushed a new field forward.

Planned meetings, papers, journals.

At the same time-

Victorian watercolors,

Japanese woodblock prints,

Indian antiquities.

You made me a collector.

With signature zest,

your learning never ceased,

whether consuming Genesis

while visiting my synagogue,

uncovering an archeologic site,

editing a new medical journal,

studying new cardiac drugs

or radiopharmaceuticals.

We talked by phone a month

before you left us.

Despite your illness,

you were vibrant, excited.

Then COVID gripped you

and refused to let go.

You died during Rosh Hashanah.

My healing prayers to no avail.

That evening an orchard

of blossoming stars,

filled a darkened sky.

One star beamed brightest.

Though the light

in your window

now extinguished,

your star will always

illuminate our nights.

Publisher's Note Springer Nature remains neutral with regard to jurisdictional claims in published maps and institutional affiliations. 